\title{
Pengaruh Kinerja Karyawan terhadap Kualitas Pelayanan Klaim pada PT. Prudential Life Assurance Pru Future Team Syariah Pekanbaru
}

\author{
LOLYTA PERMATA \\ Fakultas Agama Islam (FAI) Universitas Islam Riau (UIR) Pekanbaru \\ Jl. Kaharuddin Nasution No. 113 Perhentian Marpoyan Pekanbaru 28284 \\ e-mai: lolyt_permata@fis.uir.ac.id
}

\begin{abstract}
Abstrak: Penelitian ini bertujuan untuk mengetahui:1) kinerja karyawan dalam melayani klaim dan; 2) kualitas pelayanan klaim ganti rugi pemegang polis pada PT. Prudential Life Assurance Pru Future Team Syariah Kantor Agency Tuanku Tambusai Pekanbaru serta 3) pengaruh kinerja karyawan dalam melayani klaim terhadap kualitas pelayanan klaim ganti rugi pemegang polis pada PT. Prudential Life Assurance Pru Future Team Syariah Kantor Agency Tuanku Tambusai Pekanbaru. Populasi penelitian sebanyak 7.546 orang dan jumlah sampelnya adalah 44 orang dengan menggunakan rumus Slovin. Teknik pengambilan sampel menggunakan purposive sampling. Teknik pengumpulan data menggunakan angket. Analisis data yang digunakan adalah interpretasi skor sedangkan untuk membuktikan hipotesis penelitian menggunakan analisis regresi sederhana dengan pengolahan data menggunakan SPSS versi 17.0. Pengujian hipotesis menggunakan Uji F. Hasil penelitian ini menunjukkan bahwa: 1) Kinerja kinerja karyawan dalam melayani klaim pada PT. Prudential Life Assurance Pru Future Team Syariah Kantor Agency Tuanku Tambusai Pekanbaru tergolong baik; 2) kualitas pelayanan klaim ganti rugi pemegang polis pada PT. Prudential Life Assurance Pru Future Team Syariah Kantor Agency Tuanku Tambusai Pekanbaru tergolong baik; 3) Hasil pengujian hipotesis menunjukkan bahwa terdapat pengaruh yang signifikan antara kinerja karyawan dalam melayani klaim dengan kualitas pelayanan klaim ganti rugi pemegang polis pada PT. Prudential Life Assurance PRU Future Team Syariah kantor Agency Tuanku Tambusai Pekanbaru. Hubungan antara kinerja karyawan dalam melayani klaim dengan kualitas pelayanan klaim ganti rugi pemegang polis pada PT. Prudential Life Assurance PRU Future Team Syariah kantor Agency Tuanku Tambusai Pekanbaru merupakan hubungan cukup kuat dengan nilai koefisien korelasi bernilai positif sebesar 0,421 .
\end{abstract}

Kata kunci: perbankan syariah, akad, penghimpunan dan penyaluran dana.

\section{PENDAHULUAN}

Sumber Daya Manusia merupakan salah satu faktor yang sangat penting dalam kegiatan perusahaan karena tenaga kerja dapat berfungsi untuk menggerakkan kegiatan perusahaan, sehingga keberhasilan perusahaan dalan

pengambilan keputusan sangat dipengaruhi oleh tenaga kerja itu sendiri. Peranan tenaga kerja dalam perusahaan sangat ditentukan oleh jumlah dan mutu tenaga kerja yang tersedia untuk melaksanakan berbagai pekerjaan. 
Dalam usaha pencapaian tujuan perusahaan, permasalahan yang dihadapi manajemen bukan hanya terdapat bahan mentah, alat-alat kerja, mesin-mesin produksi, uang dan lingkungan kerja saja, tetapi juga menyangkut karyawan (sumber daya manusia) yang mengelola faktor-faktor produksi lainnya, merupakan masukan yang diolah oleh perusahaan dan menghasilkan keluaran. Karyawan baru yang belum mempunyai keterampilan dan keahlian dilatih, sehingga menjadi karyawan yang terampil dan ahli. Apabila dilatih lebih lanjut serta diberikan pengalaman dan motivasi, dia akan menjadi karyawan yang matang. Pengolahan sumber daya manusia inilah yang disebut manajemen SDM (Veithzal Rivai, 2004: 1).

Salah satunya keberhasilan suatu perusahaan asuransi dalam usaha meningkatkan profit tergantung pada sistem perencanaan pemasaran yang digunakaan oleh pihak perusahaan dalam memasarkan jasa atau produk yang dihasilkan. Dalam pemasaran ada elemen-elemen lain yang harus diperhatikan oleh pihak perusahaan, elemen-elemen tersebut adalah produk, harga, distribusi, promosi, konsumen, proses, dan bentuk fisik. Penyatuan elemen-elemen yang telah ditentukan dengan persepsi masyarakat terhadap produk atau jasa sebuah perusahaan akan menghasilkan sebuah keputusan konsumen (Nisrina Muthohari, 2012: 27).

Asuransi merupakan sarana finansial dalam tata kehidupan rumah tangga, baik dalam menghadapi risiko yang mendasar seperti risiko kematian atau dalam menghadapi risiko atas harta benda yang dimiliki. Jenis risiko yang ditanggung oleh perusahaan Asuransi juga berbeda-beda, sesuai dengan keinginan dan kebutuhan para pemegang polisnya. Secara garis besarnya perusahaan asuransi yang ada di
Indonesia dibagi menjadi empat, yakni asuransi jiwa, asuransi kerugian, asuransi reasuransi dan asuransi sosial (Djojosoedarso, 2003 : 73-74).

Berdasarkan perkembangan asuransi berbasis syariah di Indonesia tidak terlepas dari pertumbuhan bankbank syariah, di mana sejak dikeluarkannya Undang-Undang No.10/1998 yang mengatur secara tegas sistem perbankan syariah dunia perbankan di Indonesia diwarnai dengan munculnya bank-bank syariah atau bank-bank dengan unit syariahnya. Hal ini menyebabkan perusahaan-perusahaan asuransi konvensional yang memliki keterkaitan bisnis dengan bank dituntut untuk masuk ke dalam bisnis syariah, khususnya asuransi kerugian, baik dengan mendirikan perusahaan asuransi kerugian secara terpisah atau mendirikan divisi syariah. Dalam kaitannya dengan investasi, yang merupakan salah satu unsur dalam premi asuransi hanya memenuhi prinsip syariah, yaitu tidak mengenal apapun jenis riba, sedangkan semua asuransi konvensional menginvestasikan dananya dengan mekanisme bunga. Dengan demikian asuransi konvensional susah untuk menghindari riba. Lain halnya asuransi syariah dalam berinvestasi yang menyimpan dananya ke semua berbagai investasi berdasarkan prinsip syariah dengan sistem al-mudharabah (Muhammad Syakir Sula, 2004: 18).

Dengan memahami kebutuhankebutuhan para nasabah PT. Prudential Life Assurance selalu menciptakan inovasi baru dan menawarkan produkproduk yang sesuai untuk nasabah. PT.Prudential Life Assurance menawarkan produk-produk asuransi jiwa dan investasi yang lengkap guna memenuhi kebutuhan para nasabah (PT. Prudential Life Assurance, 2011: 20).

Nasabah yang ada di PT. Prudential Life Assurance Unit Syariah tahun 2013 sudah mencapai 7.546 nasabah. 
Asuransi Pru Syariah menyediakan berbagai macam produk unggulan diantaranya adalah: (a) Pru Link Syariah Assurance Account dan (b) Pru Link Investor Account (PT. Prudential Life Assurance, 2011: 20).

Berdasarkan informasi dari beberapa nasabah, adanya kesenjangan antara tuntutan pemegang polis terhadap pelayanan setelah tiba masa pertanggungan, pemegang polis keluarga yang di tinggalkan untuk mengurus pembiayaan merasa prosedurnya sulit, proses pengurusan klaim lama, sehingga nasabah merasa tingkat pemutusan kontrak pemegang polis asuransi tinggi. Hal ini mengindikasikan adanya ketidakpuasan dari pemegang polis terhadap kinerja karyawan dalam melayani klaim ganti rugi. Sehubungan dengan hal tersebut maka masalah pelayanan dalam penelitian ini dibatasi hanya dalam pelayanan klaim ganti rugi pemegang polis, sehingga masalah yang dibahas pada penelitian ini adalah: (1) Bagaimanakah kinerja karyawaan dalam melayani klaim ganti rugi pemegang polis pada PT. Prudential Life Assurance Pru Future Team Syariah Kantor Agency Tuanku Tambusai Pekanbaru? Bagaimanakah kualitas pelayanan klaim ganti rugi pemegang polis pada PT. Prudential Life Assurance Pru Future Team Syariah Kantor Agency Tuanku Tambusai Pekanbaru? (3) Apakah kinerja karyawan dalam melayani klaim berpengaruh secara signifikan terhadap kualitas pelayanan klaim ganti rugi pemegang polis pada PT. Prudential Life Assurance Pru Future Team Syariah Kantor Agency Tuanku Tambusai Pekanbaru?

\section{KONSEP TEORI}

\section{Kinerja Karyawan}

Kinerja menurut Kamus Besar Bahasa Indonesia adalah sesuatu yang dicapai, prestasi yang diperlihatkan, kemampuan kerja. Namun kesediaan dan keterampilan seseorang tidaklah cukup efektif untuk mengerjakan sesuatu tanpa pemahaman yang jelas tentang apa yang akan dikerjakan dan bagaimana mengerjakannya (Veithzal Rivai, 2004:309).

Kinerja adalah hasil yang diperoleh oleh suatu organisasi yang dihasilkan selama satu periode waktu. Sasaran yang menjadi objek penilaian kinerja adalah kecakapan, kemampuan karyawan dalam melaksanakan suatu pekerjaan atau tugas yang dievaluasi dengan menggunakan tolak ukur tertentu secara objektif dan dilakukan secara berkala. Dari hasil penilaian dapat dilihat kinerja perusahaan yang dicerminkan oleh kinerja karyawan atau dengan kata lain, merupakan hasil kerja konkret yang dapat diamati dan dapat diukur (Veithzal Rivai, 2004: 309).

Menurut Kennedy dan Young (dalam Nur Rianto, 2010: 224), terdapat lima dimensi pengukuran kepuasan pelanggan di bidang jasa sebagai berikut: (1) Avaibility of support (keberadaan pendukung). Yaitu sebagai tingkatan untuk di mana pelanggan dapat kontak dengan pemberi jasa, atau pelanggan dapat menerima penghasil jasa, dengan kata lain karyawan dapat mengetahui kebutuhan nasabah; (2) Responsiveness of support (ketanggapan pendukung). Yaitu sebagai tingkatan untuk mana pemberi jasa bereaksi cepat dan tepat terhadap permintaan pelanggan. Artinya bagaimana reaksi terhadap karyawan terhadap kebutuhaan nasabah; (3) Timeliness of support (ketepatan waktu pendukung). Yaitu sebagai tingkatan untuk mana pekerjaan dilaksanakan dalam kerangka waktu, sesuai dengan perjanjian. Artinya karyawan dapat menyelesaikan pekerjaan sesuai waktu yang disepakati; (4) Completeness of support (penyelesaian pendukung). Yaitu sebagai tingkatan untuk seluruh pekerjaan selesai atau penyelesaian 
keseluruhan pekerjaaan; (5) Pleasantness of support (kesenangan pendukung). Yaitu tingakatan untuk mana pemberi jasa berperilaku secara professional dan menggunakan cara yang profesional sewaktu bekerja.

\section{Kualitas Pelayanan}

\section{Pengertian Kualitas Pelayanan}

Kualitas pelayanan merupakan konsepsi yang abstrak dan sukar dipahami, karena kualitas pelayanan memiliki karakteristik tidak berwujud, bervariasi, tidak tahan lama, serta produksi dan konsumsi jasa terjadi secara bersamaan. Walau demikian, bukan berarti kualitas pelayanan tidak dapat diukur.

Untuk mewujudkan kualitas pelayanan pelanggan (nasabah) tentu perlu adanya kualitas pelayanan karyawan. Pelayanan kepada pelanggan (nasabah) merupakan kualitas pelayanan internal. Untuk menciptakan kualitas pelayanan internal (karyawan), pimpinan perusahaan hendaknya memberikan kompensasi yang lebih efektif kepada para karyawan. Kompensasi yang efektif memotivasi karyawan dalam meningkatkan produktivitas karyawan dan akan menciptakan karyawan memberikan kualitas pelayanan yang efektif pada pelanggan (nasabah). Dengan demikian akan menimbulkan kepuasan kepada pelanggan (nasabah) dan loyalitas pelanggan akan terjadi. Apabila pelanggan (nasabah) puas dan loyal, maka dengan sendirinya akan memberikan pertumbuhan pendapat dan peningkatan profitabilitas (M. Nur Rianto Al Arif, 2010: 223)

\section{Kriteria Pokok Kualitas Pelayanan}

Kriteria pokok kualitas pelayanan terbagi menjadi beberapa bagian, yaitu sebagai berikut (M. Nur Rianto Al Arif, 2010: 221): (1) Bukti Fisik (tangibles).
Merupakan bukti fisik yang harus dimiliki oleh karyawan perusahaan, seperti gedung, perlengkapan kantor, daya tarik karyawan, sarana komunikasi, dan sarana fisik lainnya; (2) Kehandalan (reliability), yaitu kemampuan perusahaan dalam memberikan pelayanan yang telah dijanjikan dengan cepat, akurat serta memuaskan pelanggannya; (3) Ketanggapan (responsiveness). Merupakan kemauan dari karyawan dan pengusaha untuk membantu pelanggan dan memberikan jasa dengan cepat serta mendengar dan mengatasi keluhan dari konsumen; (4) Jaminan (assurance). Berupa kemampuan karyawan untuk menimbulkan keyakinan dan kepercayaan terhadap janji yang telah dikemukakan kepada konsumen; (5) Empati (empathy), yaitu mampu memberikan kemudahan serta menjalin hubungan dengan nasabah secara efektif.

\section{Kualitas Pelayanan dalam Perspektif Islam}

Kualitas pelayanan yang diberikan perusahaan tentunya tidaklah hanya bertujuan untuk memberikan kepuasan semata. Sebagai seorang muslim dalam memberikan pelayanan haruslah mendasarkan pada nilai-nilai syariah guna mewujudkan nilai ketakwaan sekaligus membuktikan konsistensi keimanannya dalam rangka menjalankan misi syariat Islam. Tentunya hal tersebut dilakukan tidaklah hanya berorientasi pada komitmen materi semata, namun sebagai bagian dari nilai ibadah.

Dalam pandangan Islam yang dijadikan tolok ukur untuk menilai kualitas pelayanan terhadap konsumen yaitu standarisasi syariah. Islam mensyari'atkan kepada manusia agar selalu terikat dengan hukum syara' dalam menjalankan setiap aktivitas ataupun memecahkan setiap permasalahan. 
Oleh karena itu, variabel-variabel yang diuji tidaklah murni menggunakan teori konvensional saja. Namun menjadikan syariah sebagai standar penilaian atas teori tersebut. Berikut beberapa kriteria pokok kualitas pelayanan dalam perspektif Islam.

Pertama, bukti fisik (tangible), adalah suatu bentuk penampilan fisik, peralatan personal, media komunikasi dan hal-hal yang lainnya yang bersifat fisik. Salah satu catatan penting bagi pelaku lembaga keuangan syariah, bahwa dalam menjalankan operasional perusahaannya harus memperhatikan sisi penampilan fisik para pengelola maupun karyawannya dalam hal berbusana yang santun, beretika, dan syar'i. Hal ini sebagaimana yang telah Allah SWT firmankan dalam Q.S Al-A'raf ayat 26 :

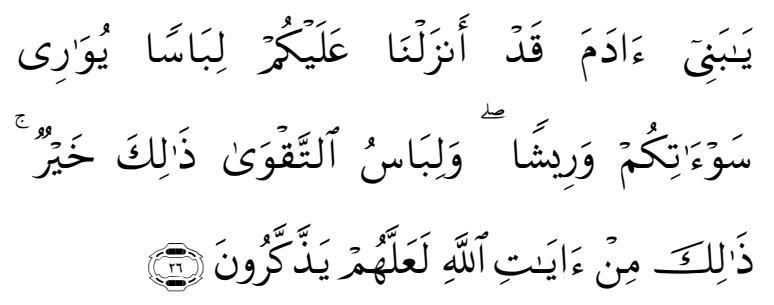

Artinya: Hai anak Adam, sesungguhnya Kami telah menurunkan kepadamu pakaian untuk menutup auratmu dan pakaian indah untuk perhiasan. Dan pakaian takwa, itulah yang paling baik. Yang demikian itu adalah sebahagian dari tanda-tanda kekuasaan Allah, mudahmudahan mereka selalu ingat (Departemen Agama RI, 1998: 121).

Kedua, Kehandalan (reliability), adalah suatu kemampuan untuk memberikan jasa yang dijanjikan dengan akurat dan terpercaya. Artinya, pelayanan yang diberikan handal dan bertanggung jawab.

Ketiga, ketanggapan (responsiveness), yang mana karyawan memiliki kemauan dan memberikan pelayanan yang cepat dan tepat kepada pelanggan. Memberikan pelayanan dengan cepat dan tepat menunjukkan pelaku bisnis yang profesional. Islam menganjurkan setiap pelaku bisnis untuk bersikap profesional yakni dapat bekerja dengan cepat dan tepat sehingga tidak menyianyiakan amanat yang menjadi tanggung jawabnya, sebagaimana terdapat dalam hadis Rasullullah saw diriwayatkan oleh Bukhari yang artinya:"Apabila amanat disia-siakan, maka tunggulah kehancurannya, berkata seseorang: bagaimana caranya menyia-nyiakan amanat ya Rasullullah? berkata Nabi: apabila diserahkan sesuatu pekerjaan kepada yang bukan ahlinya, maka tunggulah kehancurannya" (HR. Bukhari).

Keempat, jaminan (assurance), adalah kemampuan karyawan atas pengetahuan terhadap produk secara tepat, kualitas, keramah tamahan, perkataan atau kesopanan dalam memberikan pelayanan. Dalam memberikan pelayanan kepada konsumen hendaklah selalu memperhatikan etika berkomunikasi, supaya tidak melakukan manipulasi pada waktu menawarkan produk maupun berbicara dengan kebohongan. Allah SWT telah mengingatkan tentang etika berdagang sebagaimana yang diterangkan dalam Q.S Asy-Syu'araa ayat 181-182:

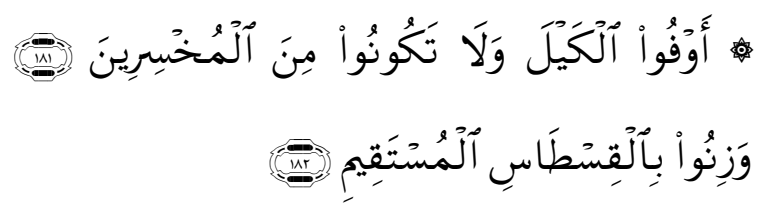

Artinya: "Sempurnakanlah takaran dan janganlah kamu termasuk orang-orang yang merugikan. Dan timbanglah dengan timbangan yang lurus" (Departemen Agama RI, 1998: 299).

Kelima, empati (empathy), ditunjukkan melalui kemudahan dalam melakukan hubungan, komunikasi yang baik, perhatian pribadi. Dalam Islam sikap empati merupakan wujud dari kemauan karyawan untuk memberikan kemudahan pada pelanggan dengan senang hati dalam melakukan transaksi. 


\section{Asuransi}

\section{Pengertian Asuransi}

Kata "asuransi" telah menjadi bagian dari kata Indonesia. Dalam Kamus Bahasa Inggris-Indonesia kata "insurance" secara linguistik, mengandung arti penjaminan (John Chols dan hasan Shadily, 2005: 326). Kata "asuransi" dalam bahasa Indonesia di defenisikan oleh tim penyusun kamus besar bahasa Indonesia, sebagai pertanggungan (perjanjian antara dua pihak, pihak yang satu berkewajiban membayar iuran dan pihak yang lain berkewajiban memberikan jaminan sepenuhnya kepada pembayar iuran, apabila terjadi sesuatu yang menimpa dirinya atau barang yang miliknya yang diansuransikan sesuai perjanjian yang dibuatnya.

Asuransi dalam pandangan ekonomi merupakan metode untuk mengurangi risiko dengan jalan memindahkan dan mengkombinasikan ketidakpastian akan adanya kerugian keuangan. Menurut sudut pandang bisnis, asuransi adalah sebuah perusahaan yang usaha utamanya menerima/menjual jasa, pemindahan risiko dari pihak lain, dan memperoleh keuntungan dengan berbagai risiko diantara sejumlah nasabah. Dari sudut pandang social asuransi sebagai sebuah organisasi social yang menerima pemindahan risiko dan mengumpulkan dana dari anggotanya guna membayar kerugian yang mungkin terjadi pada masing-masing anggota asuransi tersebut (Andri Soemitra, 2009: 244).

Perlindungan terhadap kejadian yang tidak terduga seperti gempa bumi, tsunami, tanah longsor, gunung meletus, ataupun kebakaran belum dapat diperoleh. Oleh karenanya di perlukan mekanisme lain yang mampu memberikan rasa aman yang menyeluruh serta memberikan jaminan yang komprehensif dan efektif atas semua kerugian yang timbul. Keperluan semacam itu hanya dapat diperoleh melalui pembelian polis asuransi.

\section{Pengertian Asuransi dalam Islam}

Dalam rangka menerjemahkan istilah "asuransi" ke dalam konteks asuransi Islam terdapat beberapa istilah, antara lain: takaful (bahasa arab), ta'amin (bahasa arab) dan Islamic insurance (bahasa inggris). Istilah-istilah tersebut pada dasarnya tidak berbeda satu sama lain yang mengandung pertanggungan atau saling menanggung. Namun dalam praktiknya istilah yang paling popular digunakan sebagai istilah lain dari asuransi dan juga paling banyak digunakan di berbagai negara termasuk di Indonesia adalah istilah takaful.

Istilah dalam takaful dalam bahasa arab berasal dari kata dasar kafalahyakfulu-takafala-yatakafalu-takaful yang berarti saling menanggung bersama. Kata takaful tidak dijumpai dalam AlQur'an namun demikian ada sejumlah kata yang seakar dengan kata takaful, seperti misalnya dalam QS.Thaha (20): 40 "...hal adullukum'ala man yakfuluhu...." yang artinya"...bolehkah saya menunjukan kepadamu orang yang akan memeliharanya (menanggung-nya)..." Asuransi Syariah pada hakikatnya adalah suatu bentuk kegiatan yang saling memikul di antara sesama manusia sehingga antara satu dengan yang lainnya menjadi penanggungan atas risiko yang lainnya (Abdullah Amrin, 2011: 35). Asuransi syariah (ta'min, takaful, tadhamun) adalah usaha saling melindungi dan tolong menolong di antara sejumlah orang/pihak melalui investasi dalam bentuk aset dan atau tabarru' memberikan pola pengembalian untuk menghadapi resiko tertentu melalui akad (perikatan) yang sesuai dengan syariah. Dengan akad takaffuli dan dana tabarru' tersebut menjadikan semuapeserta sebagai keluarga besar yang saling menanggung satu sama 
lainnya (Himpunan Fatwa Dewan Syariah Nasional, BI dan MUI, 2003: 129).

\section{Prinsip Dasar Asuransi Syariah}

Asuransi syariah harus dibangun dengan fondasi dan prinsip dasar yang kuat serta kokoh. Dalam hal ini prinsip utama dalam asuransi syariah adalah ta'awanu' ala birr wa al-taqwa (tolong menolonglah kamu sekalian dalam kebaikan dan taqwa) dan al-ta'min (rasa aman). Hal ini disebabkan transaksi yang dibuat dalam asuransi takaful adalah takafuli (saling menanggung), bukan akad tabaduli (saling menukar) yang selama ini digunakan oleh asuransi konvensional, yaitu pertukaran pembayaran premi dengan uang pertanggungan (Wirdyaningsih, 2002: 146).

Prinsip-prinsip dasar yang ada dalam asuransi syariah ialah sebagai berikut (Burhanuddin, 2010: 118):

Pertama, prinsip ikhtiar dan berserah diri. Manusia memiliki kewajiban untuk berusaha (ikhtiar) sesuai dengan kesanggupannya, tetapi pada saat yang bersamaan manusia juga berserah diri (tawakkal) hanya kepada Allah.

Kedua, prinsip tolong menolong (ta'awun). Prinsip paling utama dalam melaksanakan kegiatan harus didasari dengan semangat tolong menolong antara anggota. Seseorang yang masuk asuransi, sejak awal harus mempunyai niat dan motivasi untuk membantu dan meringankan beban temannya yang pada suatu ketika mendapatkan musibah/kerugian.

Ketiga, prinsip bertanggung jawab. Para peserta asuransi setuju untuk saling bertanggung jawab antara satu sama lain, dan harus melaksanakan kewajiban dibalik menerima yang menjadi hakhaknya.
Keempat, prinsip kerja samaPrinsip kerja sama atau saling membantu, yang berarti diantara peserta asuransi syariah yang satu dengan yang lainnya saling bekerja sama atau saling tolongmenolong dalam mengatasi kesulitan yang dialami karena sebab musibah yang diderita.

Kelima, prinsip saling melindungi dari berbagai kesusahan. Para peserta asuransi syariah setuju untuk saling melindungi dari musibah, kesusahan, bencana, dan sebagainya. Terutama melalui penghimpunan dana tabarru' melalui perusahaan yang diberi kepercayaan untuk itu.

\section{Perbedaan Asuransi Konvensional dan Asuransi Syariah}

Pada prinsipnya, kehadiran asuransi, baik asuransi syariah atau konvensional adalah sebagai lembaga atau jasa keuangan yang menghimpun dana masyarakat untuk meberikan perlindungan kepada anggota masyarakat pemakai jasa asuransi terhadap kemungkinan timbulnya kerugian karena suatu peristiwa yang tidak pasti datangnya, seperti kecelakaan, meninggal dunia dan lain sebagainya.

Hanya saja yang membedakan antara keduanya adalah tujuan dan sistem operasionalnya, baik dari segi struktur maupun sistem aturan yang diterapkan, sebagaimana dijelaskan berikut ini (Sofiniyah Ghufron, 2005: 2629): (1) Dalam asuransi syariah terdapat Dewan Pengawas Syariah (DPS) yang bertugas mengawasi produkyang dipasarkan dan dalam pengelolaan investasi dana. Dewan Pengawas Syariah tidak ditemukan dalam asuransi konvensional; (2) Akad yang akan dilaksanakan pada asuransi syariah berdasarkan tolong- menolong (takaful). Sedangkan dalam asuransi konvensional berdasarkan akad jual beli (tadabbuli); 
(3) Investasi dana pada asuransi syariah berdasarkan prinsip bagi hasil atau mudharabah. Sedangkan dalam asuransi konvensional berdasarkan riba sebagai dasar perhitungan investasi; (4) Pemilik dana pada asuransi syariah merupakan hak peserta. Perusahaan hanya sebagai pemegang amanah untuk mengelola. Sedangkan pada asuransi konvensional, dana yang terkumpul dari nasabah menjadi milik perusahaan sehingga perusahaan bebas menentukan alokasi investasi; (5) Dalam soal pembayaran klaim, pada asuransi takaful, dana diambil dari rekening tabarru' (dana kebajikan) seluruh peserta. Jadi sejak awal peserta sudah ikhlas bahwa ada penyisihan dana yang akan dipakai untuk menolong peserta bila terjadi musibah. Sedangkan pada asuransi konvensioanal pembayaran klaim diambil dari dana perusahaan; (6) Pada asuransi syariah takaful keuntungan dibagi antara perusahaan dengan peserta sesuai prinsip bagi hasil dengan proporsi yang telah ditentukan. Sedangkan pada asuransi konvensional seluruh keuntungan adalah milik perusahaan; (7) Dalam asuransi syariah tidak mengenal adanya dana hangus walaupun peserta asuransi ingin mengundurkan diri karena adanya satu dan lain hal, dana yang sudah disetor tetap dapat diambil, kecuali sebagian dana yang memang sudah diniatkan untuk dana tabarru'. Sedangkan dalam asuransi konvensional dikenal adanya dana hangus, dimana peserta tidak dapat melanjutkan pembayaran premi dan ingin mengundurkan diri sebelum masa jatuh tempo.

\section{Bentuk akad Asuransi Syariah}

Kata akad yang kita kenal berasal dari lafal Arab Al'aqd yang mengandung arti perikatan atau perjanjian, dan pemufakatan yang dikenal al-ittifaq. Menurut terminology fiqh kata "akad" diartikan sebagai pertalian ijab yaitu pernyataan melakukan ikatan yang sesuai dengan kehendak syariat dan berpengaruh pada sesuatu dan perikatan. Beberapa akad yang terdapat dalam asuransi syariah tidak hanya sebatas pada akad tabarru' dan mudharabah, tetapi ada jenis akad tijarah lainnya seperti al-musyarakah, alwakalah, dan al-wadiah.

Beberapa bentuk akad yang diterapkan dalam Asuransi Syariah selain akad mudharabah, adalah bentuk akad sebagai berikut (Abdullah Amrin, 2010: 105-108):

Pertama, akad wakalah. Wakalah berarti penyerahan, pendelegasian, atau pemberian mandat, yang berarti bahwa wakalah adalah pelimpahan, pendelegasian wewenang atau kuasa dari pihak pertama kepada pihak kedua untuk melaksanakan sesuatu atas nama pihak pertama. Sistem pemasaran dengan menggunakan agen merupakan salah satu penerapan dari sistem alwakalah.

Kedua, akad al-wadiah. Al-wadiah diartikan sebagai meninggalkan atau meletakkan, yaitu meletakkan sesuatu pada orang lain untuk di pelihara/dijaga. Namun menurut istilah al-wadiah adalah memberikan kekuasaan kepada orang lain untuk menjaga hartanya/barangnya dengan secara terang-terangan atau isyarat yang semakna dengan itu.

Ketiga, akad musyarakah. Musyarakah adalah keikutsertaan dua orang atau lebih dalam suatu usaha tertentu dengan sejumlah modal yang telah ditetapkan berdasarkan perjanjian bersama-sama untuk menjalankan sesuatu dan pembagian keuntungan dan kerugian dalam bagian yang ditentukan.

\section{Polis Asuransi \\ Pengertian Polis}

Polis adalah dokumen yang memuat pertanggungan antara 
pemegang polis dan penanggung (perusahaan), yang isinya terdiri dari ringkasan polis, ketentuan polis, fotokopi surat permintaan asuransi jiwa, serta fotokopi formulir dan dokumen lainnya yang merupakan bagian tidak terpisahkan atau dinyatakan sebagai bagian dari polis itu sendiri (Heru Susanto, 2010: 9-11).

Polis asuransi adalah surat perjanjian antara pihak yang menjadi peserta asuransi dengan perusahaan asuransi. Polis asuransi merupakan bukti akta mengenai adanya perjanjian asuransi. Polis asuransi merupakan dasar perjanjian antara pemegang polis dengan perusahaan setelah memenuhi persyaratan yang telah ditentukan.

\section{Fungsi Polis}

Fungsi polis terdiri dari tiga, yaitu fungsi umum dan fungsi bagi tertanggung dan penanggung (Frianto, Elly, dan Ahcmad Abror, 2005: 138-139).

Pertama, fungsi umum polis asuransi: (a) Perjanjian pertanggungan (a contract of indemnity); (b) Sebagai bukti jaminan dari penanggung kepada tertanggung untuk mengganti kerugian yang mungkin akan dialami oleh tertanggung akibat peristiwa yang tidak diduga sebelumnya; (c) Untuk mengembalikan tertanggung kepada kedudukannya semula sebelum terjadi/mengalami kerugian; (4) Bukti pembayaran premi asuransi oleh tertanggung kepada penanggung sebagai balas jasa atas jaminan penanggung.

Kedua, fungsi polis bagi tertanggung: (a) Sebgai bukti tertulis atas jaminan penanggungan untuk mengganti kerugian yang mungkin akan dideritanya yang ditanggung oleh polis; (b) Sebagai bukti (kwitansi) pembayaran premi kepada penanggung; (c) Sebagai bukti untuk menuntut penanggung bila lalai atau tidak mematuhi jaminannya.
Ketiga, fungsi polis bagi penanggung: (a) Sebagai bukti (tanda terima) premi asuransi dari tertanggung; (b) Sebagai bukti tertulis atas jaminan yang diberikannya kepada tertanggung. untuk membayar ganti rugi yang mungkin diderita oleh tertanggung; (c) Sebagai bukti autentik untuk menolak tuntutan ganti rugi (klaim) bila yang menyebabkan kerugian tidak memenuhi syarat-syarat polis.

\section{Premi Asuransi \\ Pengertian Premi}

Premi asuransi adalah sejumlah uang sebagaimana tercantum dalam polis yang di setujui oleh pemegang polis untuk dibayarkan kepada perusahaan asuransi sesuai dengan perjanjian agar polis tetap aktif. Premi pertama, premi lanjutan, premi perpanjangan, dan premi perubahan polis merupakan jenis-jenis premi (Nisrina Muthohari, 2012: 14).

\section{Fungsi Premi}

Fungsi premi asuransi adalah sebagai berikut: (1) Mengembalikan tertanggung pada posisi ekonomi seperti sebelum terjadi kerugian; (2) Menghindarkan tertanggung dari kebangkrutan sedemikian rupa, sehingga mampu berdiri pada posisi seperti keadaan sebelum terjadi kerugian.

\section{PT. Prudential Life Assurance \\ Perkembangan PT. Prudential Life Assurance}

Prudential Life Assurance merupakan perusahaan jasa keuangan terkemuka asal Inggris. Prudential plcmemiliki tujuan untuk membantu masyarakat dalam merencanakan keuangan mereka dan keluarga, dengan cara menyediakan produk-produk untuk mengatasi risiko keuangan yang sesuai dengan rencana keuangan yang dipilih. 
Grup Prudential memiliki posisi yang kuat pada 3 pasar terbesar dan paling menguntungkan di dunia, yaitu Inggris Raya dan Eropa, Amerika Serikat, dan Asia. Prudential senantiasa menjaga hubungan yang harmonis dan berkesinambungan dengan para nasabah, melalui penyediaan berbagai produk dan jasa yang menawarkan nilai tambah dari sisi keuangan dan perlindungan.

\section{Produk-produk PT. Prudential Life Assurance}

Prudential Indonesia menawarkan produk-produk asuransi jiwa, investasi yang lengkap guna memenuhi kebutuhan para nasabah dan produk yang sesuai dengan gaya hidup dan tujuan finansial nasabah. Adapun produk-produk unit link sebagai berikut:

Pertama, PRU link assurance account (PAA). Produk asuransi jiwa yang dikaitkan dengan investasi yang memberikan perlindungan asuransi jiwa sekaligus keuntungan berinvestasi, dan juga telah dirancang untuk memberikan fleksibilitas yang dapat memenuhi kebutuhan dalam setiap tahapan kehidupan anda. Manfaat PRU link assurance account adalah: (1) Jaminan manfaat kematian; (2) Manfaat cacat total dan tetap; (3) Dapat menambahkan nilai uang pertanggungan; (4) Dapat melakukan penambahan premi setiap saat; (5) Dapat menentukan sendiri besarnya komposisi dan nilai proteksi dan nilai investasi; (6) Dapat melakukan pengalihan dana; (7) Pilihan manfaat asuransi tambahan yang beragam.

Kedua, PRU link investor account (PIA). Produk unit link dengan pembayaran premi sekaligus yang menawarkan berbagai pilihan dana investasi. Di samping mendapatkan hasil investasi yang optimal, produk ini juga akan memberikan perlindungan yang komprehensif terhadap risiko kematian atau risiko menderita cacat total dan tetap.

\section{Klaim dalam PT. Prudential Life Assurance}

Definisi klaim menurut modul Lisensi AAJI adalah tuntutan yang diajukan pemegang polis terhadap pelayanan atau janji yang diberikan penanggung pada saat kontrak asuransi dibuat. Ketika klaim muncul, perusahaan asuransi sebagai penanggung harus melaksanakan kewajiban sebagaimana tertera di dalam polis.

Pengajuan atas suatu klaim dapat dipenuhi, jika memenuhi beberapa persyaratan antara lain sebagai berikut: (1) Memiliki produk yang akan diklaim. Jenis-jenis produk yang dapat diklaim oleh pemegang polis antara lain: (a) Produk Dasar yaitu PRU Link (syariah) investor account (PIA), PRU Link (syariah) assurance account (PAA), PRU my child; (b) Manfaat tambahan/riders dalam PRU link (syariah) assurance account (PAA); (2) Polis masih inforce/berlaku aktif; (3) Sudah melewati masa tunggu (waiting period) yang berlaku dalam masing-masing manfaat; (4) Tidak termasuk dalam pengecualian (exclusion); (5) Tidak mengungkapkan informasi yang bersifat material mengenai kondisi kesehatan nasabah kepada perusahaan; (6) Melihat kriteria Polis yang akan diklaim; (7) Kelengkapan dokumen pengajuan klaim. Berikut ini adalah standar pelayanan polis Prudential. 
Tabel 1: Standar Pelayanan Polis Prudential

\begin{tabular}{lc}
\hline \multicolumn{1}{c}{ Bagian Klaim Pemegang Polis } & Jumlah Hari \\
\hline PRUmed & 9 hari \\
\hline PRUhospital \& surgical reimbursement & 11 hari \\
\hline Kondisi Kritis & 20 hari \\
\hline Waiver & 20 hari \\
\hline Meninggal & 20 hari \\
\hline Cacat Tetap dan Total & 20 hari \\
\hline PRU personal accident death \& disablement & 20 hari \\
\hline
\end{tabular}

Pembayaran klaim dalam asuransi syariah diambil dari dana tabarru' semua peserta dan hasil investasi. Perusahaan sebagai Mudharib berkewajib untuk menyelesaikan proses klaim secara cepat, tepat dan efisien sesuai dengan amanah yang diterimanya. Sebagaimana firman Allah SWT, dalam surat al-Anfaal ayat 27 :

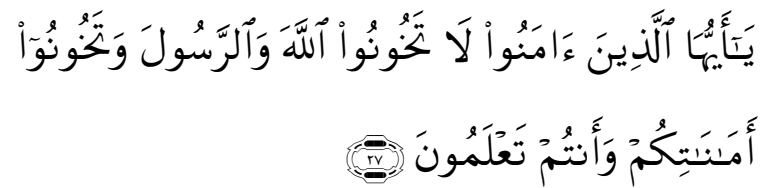

Artinya: "Hai orang-orang yang beriman, janganlah kamu mengkhianati Allah dan Rasul (Muhammad) dan (juga) janganlah kamu mengkhianati amanat-amanat yang dipercayakan kepadamu, sedang kamu mengetahui." (Departemen Agama RI, 1998: 143).

Perusahaan asuransi syariah di dalam menyelesaikan klaim berupa kerusakan atau kerugian terhadap peserta dengan cara mengacu pada akad kondisi dan kesepakatan yang tertulis dalam polis, yaitu dengan dua pilihan; pertama akan mengganti dengan uang tunai, kedua memperbaiki atau membangun ulang objek yang mengalami kerusakan. Prosedur penyelesaian klaim baik asuransi kerugian syariah maupun konvensional hampir sama, kecuali dalam hal kecepatan dan kejujuran dalam menilai suatu klaim (Abdullah Amrin, 2011: 198).

Penelitian tentang kinerja karyawan dan kualitas pelayanan telah diteliti antara lain oleh Afrida Wahyuli
(2009) yang berjudul "Pengaruh Pelatihan terhadap Kinerja Karyawan Pada PT. Bank Perkreditan Rakyat Syariah (BPRS) Berkah Dana Fadhillah Di Airtiris Kabupaten Kampar". Penelitian ini menunjukkan bahwa adanya pelaksanaan pelatihan cukup berpengaruh terhadap peningkatan kinerja karyawan pada PT. BPRS Berkah Dana Fadhillah di Airtiris Kabupaten Kampar". Hasil penelitian ini menunjukkan bahwa adanya pelaksanaan pelatihan cukup berpengaruh terhadap peningkatan kinerja karyawan pada PT. BPRS Berkah Dana Fadhillah di Airtiris Kabupaten Kampar".

Selain itu penulis juga menemukan penelitian Khaira Dewi (2014) Kinerja Karyawan dalam Melayani Klaim Ganti Rugi Pemegang Polis Pada PT. Prudential Life Assurance PRU Future Team Syariah Kantor Agency Tuanku Tambusai Pekanbaru. Hasil penelitian ini menunjukkan bahwa kinerja karyawan dalam melayani pemegang polis pada PT. Prudential Life Assurance sudah baik dengan persentase $73,79 \%$.

Perbedaan penelitian ini dengan penelitian yang lain adalah variabelvariabel yang akan diteliti yaitu terdiri dari dua variabel yaitu kinerja karyawan dan kualitas pelayanan. Selain itu penelitian ini menyempurnakan penelitian yang dilakukan oleh Khaira Dewi (2014) yang Kinerja Karyawan dalam Melayani Klaim Ganti Rugi Pemegang Polis Pada PT. Prudential Life Assurance PRU Future Team Syariah 
Kantor Agency Tuanku Tambusai Pekanbaru yang dianalisis secara deskriptif, sedangkan pada penelitian ini penulis menganlisis secara deskriftif dan infrerensial dengan dua variabel yang terdiri dari kinerja karyawan dalam melayani klaim sebagai variabel bebas dan kualitas pelayanan klaim ganti rugi pemegang polis sebagai variabel terikat.

Untuk mengetahui pengaruh kinerja karyawan terhadap kualitas pelayanan klaim pada PT. Prudential Life Assurance Pru Future Team Syariah Pekanbaru maka hipotesis penelitian ini adalah terdapat pengaruh yang signifikan antara kinerja karyawan dalam melayani klaim terhadap kualitas pelayanan klaim ganti rugi pemegang polis pada PT. Prudential Life Assurance Pru Future Team Syariah Kantor Agency Tuanku Tambusai Pekanbaru.

\section{METODE}

Penelitian ini dilakukan di PT Prudential Life Assurance PRU Future Team Syariah yang berada di Jl. Tuanku Tambusai No. 8 Pekanbaru. Penelitian ini dilakukan pada bulan Oktober sampai bulan Desember 2014.

Populasi penelitian ini adalah seluruh nasabah yang menggunakan jasa asuransi jiwa pada PT. Prudential Life Assurance tahun 2013 sebanyak 7.546 orang. Sampel penelitian ini dihitung dengan menggunakan rumus slovin yang dibulatkan menjadi 44 nasabah. Sedangkan teknik pengambilan sampel dalam penelitian ini menggunakan purposive sampling, yaitu sampel disesuaikan dengan kriteria tertentu yang mempunyai sangkut paut yang erat dengan populasi yang diketahui sebelumnya (Nurul Zuriah, 2009: 124). Kiriteria pengambilan sampel yang ditentukan dalam penelitian ini adalah nasabah yang hanya pemegang polis syariah.
Data yang digunakan dalam penelitian ini adalah data primer yang diperoleh dari responden teknik pengumpulan data menggunakan angket dengan menggunakan skala likert dan data sekunder yang diperoleh dari literatur yang berkaitan dengan masalah yang diteliti.

Teknik pengolahan data dalam penelitian ini adalah (1) Editing (penyuntingan), yaitu meneliti kembali data yang telah dikumpulkan dengan menilai apakah data yang telah dikumpulkan tersebut cukup baik atau relevan untuk diproses atau diolah lebih lanjut; (2) Coding (pengkodean), yaitu usaha pengklasifikasian jawaban dari responden menurut macamnya dengan memberikan kode tertentu;

Penyusunan buku kode, yaitu digunakan sebagai pedoman oleh peneliti untuk memindahkan jawaban dalam angket ke lembaran yang telah ditentukan; (4) Tabulating (tabulasi), yaitu proses penyusunan data dalam bentuk tabel (Moh. Pabundu Tika, 2006: 75-81).

Teknik analisis data menggunakan dalam penelitian ini adalah analisis deskriptif dan analisis inferensial.

Uji validitas dilakukan untuk mengetahui tingkat validitas (keabsahan) dari instrumen penelitian (angket) yang akan digunakan dalam mengumpulkan data. Uji validitas ini dilakukan untuk mengetahui apakah butir-butir yang tersaji dalam angket benar-benar mampu menggambarkan dengan pasti apa yang diteliti. Menurut Azwar dan Soegiyono (dalam Suliyanto, 2006: 149), skor butir pernyataan dianggap valid apabila nilai koefisien korelasi product moment melebihi 0,3.

Sedang uji reliabilitas untuk mengetahui adanya konsistensi alat ukur dalam penggunaannya atau dengan kata lain, alat ukur tersebut mempunyai hasil konsisten apabila digunakan berkali-kali pada waktu yang berbeda. Uji reliabilitas 
pada penelitian ini menggunakan Cronbach's Alpa.

Setelah data dinyatakan valid dan reliabel maka data dianalisis menggunakan analisis regresi linier sederhana. Analisis regresi linier sederhana adalah untuk meramalkan (memprediksi) varibel terikat (Y) bila variabel bebas $(\mathrm{X})$ diketahui. Regresi sederhana dapat dianalisis karena didasarkan hubungan fungsional atau sebab akibat (kausal) dari variabel bebas $(\mathrm{X})$ terhadap varibel terikat (Y). Dengan analisis tersebut maka dapat juga dilihat kuat lemahnya pengaruh antara variabel dengan menggunakan nilai koefisien korelasi dan koefisien determinasi.
Koefisien korelasi merupakan bilangan yang digunakan untuk mengukur keeratan hubungan antar variabel. Untuk mengetahui nilai koefisien korelasi maka digunakan rumus korelasi Pearson Product Moment sebagai berikut (dalam Riduwan, 2009: 227):

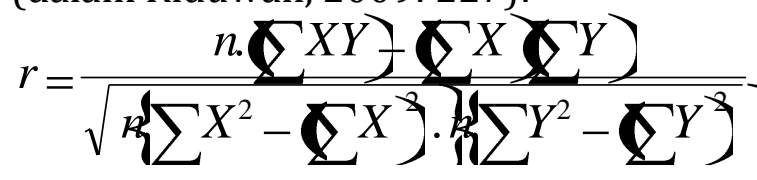

Untuk memberikan interpretasi hubungan antara variabel bebas (X) dengan variabel terikat (Y) dapat digunakan tabel berikut ini (Riduwan, 2009: 228):

Tabel 2: Interpretasi Koefisien Korelasi

\begin{tabular}{cc}
\hline Interval Koefisien & Tingkat Hubungan \\
\hline $0,00-0,199$ & Sangat Rendah \\
\hline $0,20-0,399$ & Rendah \\
\hline $0,40-0,599$ & Cukup \\
\hline $0,60-0,799$ & Kuat \\
\hline $0,80-1,000$ & Sangat Kuat \\
\hline
\end{tabular}

Koefisien determinasi (koefisien penentu) digunakan untuk mengukur seberapa besar kontribusi variabel bebas (X) terhadap variabel terikat (Y).

Langkah pengujian yang dilakukan adalah menentukan taraf signifikan penelitian $(\alpha)$ sebesar $5 \%$, kemudian menentukan nilai $t$ tabel dengan ketentuan $\mathrm{dk}=\mathrm{n}-1$. Kriteria pengujiannya adalah jika $\mathrm{F}$ hitung $\geq \mathrm{F}$ tabel maka Ho ditolak dan Ha diterima artinya terdapat pengaruh yang signifikan antara variabel bebas (X) terhadap variabel terikat (Y) dan jika $\mathrm{F}$ hitung $\leq \mathrm{F}$ tabel maka Ho dierima dan $\mathrm{Ha}$ ditolak tidak terdapat pengaruh signifikan antara variabel bebas (X) terhadap variabel terikat (Y).

\section{HASIL}

Gambaran Umum Perusahaan Sejarah Berdirinya PT. Asuransi Life Asurance

Prudential plc merupakan perusahaan jasa keuangan terkemuka asal Inggris yang didirikan pada $30 \mathrm{Mei}$ 1848 di Hatton Garden London dengan nama The Prudential Mutual Assurance Investment and Loan Association yang menyediakan pinjaman kepada para professional dan pekerja. Pada tahun 1854 perusahaan mulai menjual konsep baru polis asuransi yang ditujukan kepada kelas pekerja dengan konsep door to door salesman yang dikenal dengan julukan "Man from the Pru". Pada tahun 1879 home base-nya pindah ke Holborn Bars dan menjadi PT pada tahun 1881.

Grup Prudential memiliki posisi yang kuat pada 3 pasar terbesar dan paling menguntungkan di dunia, yaitu 
Inggris Raya dan Eropa, Amerika Serikat, dan Asia. Pada ketiga pasar ini, kekayaan global yang terus meningkat dan demografi yang dinamis memunculkan permintaan besar untuk produk proteksi jangka panjang dengan investasi.

Prudential UK (Inggris Raya) adalah penyedia jasa asuransi jiwa dan dana pensiun terkemuka di Inggris Raya. Memiliki lebih dari 7 juta nasabah dan 3000 karyawan (data per 31 Desember 2009). Prudential beroperasi di Belfast, Dublin, London, Reading, dan Stirling.

Prudential Corporation Asia (PCA). Di Asia, Prudential telah memiliki pengalaman lebih dari 80 tahun dengan dibukanya unit bisnis Prudential pertama di Malaysia.Kantor regional Prudential di Asia adalah PCA di Hongkong yang didirikan tahun 1994. Kini, Prudential di Asia telah berhasil menjadi salah satu grup perusahaan asuransi jiwa dan pengelolaan dana di 13 negara, yaitu: Cina, Filipina, Hongkong, India, Indonesia, Jepang, Korea Selatan, Malaysia, Singapura, Taiwan, Thailand, Australia dan Vietnam.

PT. Prudential Life Assurance (Prudential Indonesia) didirikan pada tahun 1995. Prudential Indonesia merupakan bagian dari Prudential plc, London, Inggris dan di Asia Prudential Indonesia menginduk pada kantor regional PCA, yang berkedudukan di Hongkong. Dengan menggabungkan pengalaman internasional Prudential di bidang asuransi jiwa dengan pengetahuan tata cara bisnis lokal, Prudential Indonesia memiliki komitmen untuk terus mengembangkan bisnisnya di Indonesia.

Prudential Indonesia telah menjadi pemimpin pasar dalam penjualan produk asuransi jiwa yang dikaitkan dengan investasi (unit link) sejak pertama kali meluncurkan produk ini di tahun 1999. Prudential Indonesia selalu berusaha untuk menyediakan produk unit link yang dirancang untuk memenuhi dan melengkapi kebutuhan nasabahnya, dalam setiap tahap kehidupan, mulai dari usia kerja, pernikahan, kelahiran anak, pendidikan anak, hingga masa pensiun.

\section{Sejarah Singkat Berdirinya Kantor Agency PRU Future Team Syariah Pekanbaru}

Kantor Agency Future Team Pekanbaru merupakan salah satu cabang agency penjualan produk-produk asuransi Prudential yang berada di Jl. Tuanku Tambusai Pekanbaru. Pembentukan Kantor Agen Prudential PRU Future Pekanbaru melalui surat keputusan DIREKSI No.SK.01/DIR/PRU Future Team 2006. Tanggal 01 November 2006 dan diresmikan oleh Direktur Utama tanggal 23 November 2006. Kantor Agen ini didirikan dengan menggunakan modal pemiliknya sendiri. Pemiliknya mendirikan kantor agen ini melalui kerja keras yang dimulai dari bawah pada saat mulai bergabung dengan PT. Prudential Life Assurance. Dengan ketekunan dan kerja kerasnya dalam menjalankan bisnis asuransi ini maka dapat mendirikan Kantor Agen ini, pemiliknya menduduki tingkatan sebagai Agency Manager.

\section{Visi dan Misi}

Visi PT. Prudential Life Assurance adalah menjadi perusahaan nomor satu di Asia, dalam hal: (1) pelayanan nasabah; (2) memberikan hasil terbaik bagi para pemegang saham; (3) mempekerjakan orang-orang terbaik. Misi PT. Prudential Life Assurance adalah Menjadi perusahaan jasa keuangan ritel terbaik di Indonesia, melampaui pengharapan para nasabah, tenaga pemasaran, staf dan pemegang saham dengan memberikan pelayanan terbaik, produk berkualitas, staf serta tenaga pemasaran professional yang berkomitmen tinggi serta menghasilkan 
pendapatan

menguntungkan.

\section{Analisis Deskriptif \\ Kinerja Karyawan dalam Melayani Klaim}

Kinerja karyawan dalam melayani klaim nasabah pemegang polis terdiri dari lima dimensi yaitu keberadaan (availibility), ketanggapan (responsivenes), ketepatan waktu (timelines), penyelesaian (completeness) dan kesenangan (pleasantness) yang dibagi dalam indikator-indikator dalam angket penelitian. Hasil jawaban dari responden tentang kinerja karyawan dalam melayani klaim dapat dilihat dalam tabel di bawah ini:

Tabel 3: Hasil Jawaban Responden tentang tentang kinerja karyawan dalam melayani klaim pada PT. Prudential Life Assurance PRU Future Team Syariah kantor Agency Tuanku Tambusai Pekanbaru

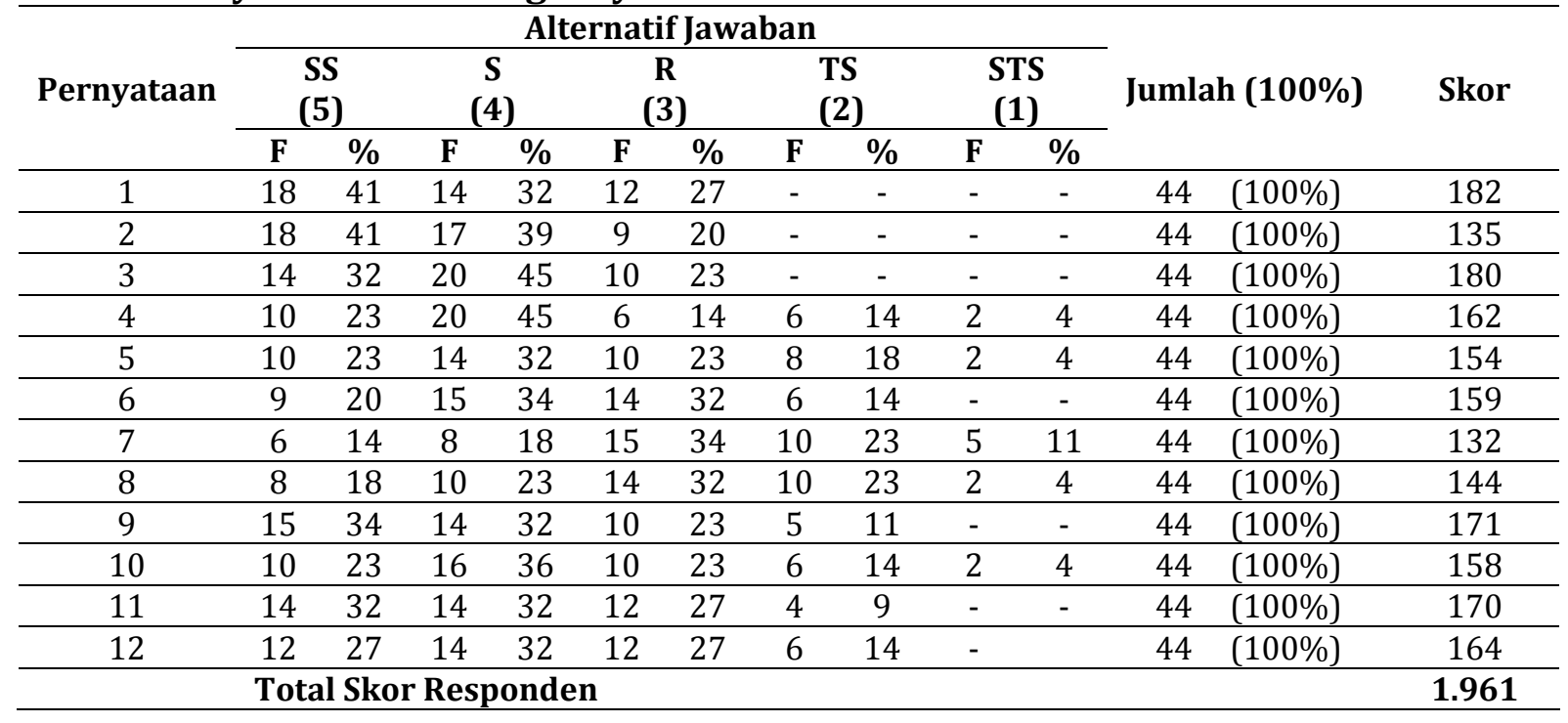

Berdasarkan tabulasi data di atas dapat diinterpretasikan berdasarkan skor untuk mengetahui tingkat kinerja karyawan dalam melayani klaim pemegang polis. Kriteria interpretasi skor yaitu: 1) Sangat baik, jika skor terletak antara 81\% - 100\%; 2) Baik, jika skor terletak antara $61 \%$ - 80\%; 3) Cukup Baik, jika jika skor terletak antara 41\% - 60\%; 4) Buruk, jika skor terletak antara 21\% - 40\% dan 5) Sangat buruk, jika skor terletak antara 0\% - 20\%.

Dari data di atas dapat diketahui bahwa kinerja karyawan dalam melayani klaim nasabah pemegang polis adalah tergolong baik $(1.961 / 2.640 \times 100 \%=$ $74,28 \%)$.

\section{Kualitas Pelayanan Klaim Ganti Rugi Pemegang Polis}

Kualitas pelayanan klaim ganti rugi nasabah pemegang polis terdiri dari lima dimensi terdiri dari lima dimensi yaitu bukti fisik (tangible), kehandalan (reliability), ketanggapan (responsiveness), jaminan (assurance) dan empati (emphaty) yang dibagi dalam indikatorindikator dalam angket penelitian. Hasil jawaban dari responden tentang kualitas pelayanan klaim ganti rugi pemegang polis dapat dilihat dalam tabel di bawah ini: 
Tabel 4: Hasil Jawaban Responden tentang kualitas pelayanan klaim ganti rugi pemegang polis pada PT. Prudential Life Assurance PRU Future Team Syariah kantor Agency Tuanku Tambusai Pekanbaru

\begin{tabular}{|c|c|c|c|c|c|c|c|c|c|c|c|c|}
\hline \multirow{3}{*}{ Pernyataan } & \multicolumn{10}{|c|}{ Alternatif Jawaban } & \multirow{3}{*}{ Jumlah (100\%) } & \multirow{3}{*}{ Skor } \\
\hline & \multicolumn{2}{|c|}{$\begin{array}{c}\text { SS } \\
\text { (5) }\end{array}$} & \multicolumn{2}{|c|}{$\begin{array}{c}S \\
(4)\end{array}$} & \multicolumn{2}{|c|}{$\begin{array}{c}\mathbf{R} \\
(3) \\
\end{array}$} & \multicolumn{2}{|c|}{$\begin{array}{l}\text { TS } \\
(2) \\
\end{array}$} & \multicolumn{2}{|c|}{$\begin{array}{l}\text { STS } \\
\text { (1) }\end{array}$} & & \\
\hline & $\mathbf{F}$ & $\%$ & $\mathbf{F}$ & $\%$ & $\mathbf{F}$ & $\%$ & $\mathbf{F}$ & $\%$ & $\mathbf{F}$ & $\%$ & & \\
\hline 1 & 21 & 48 & 23 & 52 & 0 & - & - & & - & - & $(100 \%)$ & 197 \\
\hline 2 & 20 & 46 & 19 & 43 & 5 & 11 & - & & - & - & $44 \quad(100 \%)$ & 191 \\
\hline 3 & 12 & 27 & 28 & 64 & 4 & 9 & - & & - & - & $(100 \%)$ & 184 \\
\hline 4 & 10 & 23 & 20 & 45 & 7 & 16 & 5 & 11 & 2 & 5 & $(100 \%)$ & 163 \\
\hline 5 & 18 & 41 & 15 & 34 & 11 & 25 & - & & - & - & $(100 \%)$ & 183 \\
\hline 6 & 18 & 41 & 15 & 34 & 11 & 25 & - & & - & - & $(100 \%)$ & 183 \\
\hline 7 & 9 & 20 & 15 & 34 & 14 & 32 & 6 & 14 & - & - & $(100 \%)$ & 159 \\
\hline 8 & 12 & 27 & 14 & 32 & 12 & 27 & 6 & 14 & - & - & $(100 \%)$ & 164 \\
\hline 9 & 10 & 23 & 20 & 45 & 6 & 14 & 6 & 14 & 2 & 4 & $(100 \%)$ & 162 \\
\hline 10 & 15 & 34 & 14 & 32 & 10 & 23 & 5 & 11 & - & - & $(100 \%)$ & 171 \\
\hline 11 & 10 & 23 & 14 & 32 & 10 & 23 & 8 & 18 & 2 & 4 & $(100 \%)$ & 154 \\
\hline 12 & 18 & 41 & 17 & 39 & 9 & 20 & - & & - & - & $(100 \%)$ & 185 \\
\hline 13 & 13 & 30 & 14 & 23 & 12 & 27 & 5 & 11 & - & - & $(100 \%)$ & 167 \\
\hline 14 & 10 & 23 & 16 & 36 & 10 & 23 & 6 & 14 & 2 & 4 & $44 \quad(100 \%)$ & 158 \\
\hline
\end{tabular}

Berdasarkan tabulasi data di atas dapat diinterpretasikan berdasarkan skor untuk mengetahui tingkat kinerja karyawan dalam melayani klaim nasabah pemegang polis. Kriteria interpretasi skor yaitu: 1) Sangat baik, jika skor terletak antara 81\% - 100\%; 2) Baik, jika skor terletak antara $61 \%$ - 80\%; 3) Cukup Baik, jika jika skor terletak antara $41 \%-60 \%$; 4) Buruk, jika skor terletak antara 21\% - 40\% dan 5) Sangat buruk, jika skor terletak antara 0\% - 20\%.

Dari tabel 4 di atas dapat diketahui skor yang diperoleh dari responden adalah 2.421 sedangakan skor ideal (skor tertinggi) $=14 \times 44 \times 5=3.080$. Dari data di atas dapat diketahui bahwa kinerja karyawan dalam melayani klaim nasabah pemegang polis adalah tergolong baik $(2.421 / 3.080 \times 100 \%=$ $78,60 \%)$.

\section{Analisis Inferensial}

Analisis inferensial digunakan untuk menjawab hipotesis penelitian. Analisis yang digunakan adalah analisis regresi linier sederhana. Sebelum dilakukan analisis regresi maka uji validitas. Data dinyatakan valid apabila $r_{\text {hitung }}>\mathrm{r}$ tabel. Uji validitas dilakukan menggunakan SPSS for windows versi 17.0. Berdasarkan hasil uji validitas untuk variabel $\mathrm{X}$, dari 12 butir pernyataan terdapat 7 butir pernyataan yang valid dan 5 butir pernyataan yang tidak valid. Sedangkan hasil uji validitas untuk variabel $Y$, dari 14 butir pernyataan terdapat 10 butir pernyataan yang valid dan 4 butir pernyataan yang tidak valid.

Uji reliabilitas dilakukan dengan menggunakan rumus cronbach's alpha dimana instrumen dinyatkan reliabel apabila nilai cronbach's alpha mencapai 0,6 atau lebih. Uji realibilitas dilakukan menggunakan SPSS for windows versi 17.0. Berdasarkan uji validitas dan reliabilitas di atas dapat dinyatakan bahwa 7 butir pernyataan untuk variabel $\mathrm{X}$ dan dan 9 butir pernyataan untuk variabel Y dinyatakan valid dan reliabel.

Setelah data dinyatakan valid dan reliabel maka data sudah dapat dianalisis menggunakan regresi liner. Dengan menggunakan program SPSS for 
windows versi 17.0 maka diperoleh nilai-

berikut:

nilai untuk regresi linier adalah sebagai

Tabel 5: Analisis Regresi Linier

\begin{tabular}{|c|c|c|c|c|c|c|}
\hline & \multirow[t]{2}{*}{ Model } & \multicolumn{2}{|c|}{$\begin{array}{l}\text { Unstandardized } \\
\text { Coefficients }\end{array}$} & \multirow{2}{*}{$\begin{array}{c}\begin{array}{c}\text { Standardized } \\
\text { Coefficients }\end{array} \\
\text { Beta }\end{array}$} & \multirow[t]{2}{*}{$\mathbf{F}$} & \multirow[t]{2}{*}{ Sig. } \\
\hline & & B & Std. Error & & & \\
\hline \multirow[t]{3}{*}{1} & (Constant) & 25,498 & 4,655 & & 9,027 & 0,004 \\
\hline & $\begin{array}{l}\text { Kinerja Karyawan } \\
\text { dalam melayani klaim }\end{array}$ & 0,530 & 0,176 & 0,421 & & \\
\hline & $\begin{array}{c}\mathbf{R} \\
\mathbf{R}^{2}\end{array}$ & $\begin{array}{l}=0,421 \\
=0,177\end{array}$ & & & & \\
\hline
\end{tabular}

Berdasarkan tabel 5 di atas, maka dapat disusun persamaan regresi sederhana sebagai berikut: $\hat{Y}=25,498+0,530 X$, yang artinya, nilai a = 25,498 menunjukan bahwa apabila nilai variabel $\mathrm{X}=0$ maka nilai variabel $\mathrm{Y}$ sebesar 25,498 dan nilai $b=0,530$ menunjukan bahwa apabila nilai variabel $\mathrm{X}$ naik satu satuan maka nilai variabel $\mathrm{Y}$ akan mengalami kenaikan 0,530 satuan.

Berdasarkan tabel 5 di atas dapat diketahui juga kuat lemahnya hubungan antara variabel $\mathrm{X}$ dan $\mathrm{Y}$. Hubungan kinerja karyawan dalam melayani klaim dengan kualitas pelayanan klaim ganti rugi pemegang polis pada PT. Prudential Life Assurance Pru Future Team Syariah Kantor Agency Tuanku Tambusai Pekanbaru adalah hubungan sedang, hal ini diketahui dari nilai $r$ (koefisien korelasi) sebesar 0,421. Sedangkan kontribusi variabel kinerja karyawan dalam melayani klaim sebesar 17,70\% terhadap kualitas pelayanan klaim ganti rugi pemegang polis pada PT. Prudential Life Assurance PRU Future Team Syariah kantor Agency Tuanku Tambusai Pekanbaru sedangkan sisanya sebesar $82,30 \%$ dipengaruhi oleh faktor lain.

Berdasarkan analisis regresi maka dilakukan pengujian hipotesis. Berdasarkan pengujian hipotesis diketahui $F$ hitung $(9,027)>F$ tabel $(4,07)$ berarti bahwa Ho ditolak dan Ha diterima, artinya terdapat pengaruh yang signifikan antara kinerja karyawan dalam melayani klaim dengan kualitas pelayanan klaim ganti rugi nasabah pemegang polis pada PT. Prudential Life Assurance PRU Future Team Syariah kantor Agency Tuanku Tambusai Pekanbaru.

\section{PEMBAHASAN}

Berdasarkan hasil penelitian dapat diketahui bahwa kinerja karyawan dalam melayani klaim pada PT. Prudential Life Assurance PRU Future Team Syariah kantor Agency Tuanku Tambusai Pekanbaru tergolong baik karena skor empiris dibandingkan dengan skor idealnya sebesar $74,28 \%$ ternasuk pada kriteria interpretasi skor 61\% - 80\%. Sedangkan kualitas pelayanan klaim ganti rugi pemegang polis pada PT. Prudential Life Assurance PRU Future Team Syariah kantor Agency Tuanku Tambusai Pekanbaru tergolong baik karena skor empiris dibandingkan dengan skor idealnya sebesar 78,60\% ternasuk pada kriteria interpretasi skor $61 \%-80 \%$.

Berdasarkan analisis regresi diperoleh persamaan regresi sederhana sebagai berikut: $\hat{Y}=25,498+0,530 X$, yang artinya nilai a sebesar 25,498 menunjukan bahwa apabila nilai variabel 
kinerja karyawan dalam melayani klaim (X) sebesar 0 maka nilai variabel kualitas pelayanan klaim ganti rugi pemegang polis (Y) sebesar 25,498. Sedangkan nilai b sebesar 0,530 menunjukan bahwa apabila nilai variabel kinerja karyawan dalam melayani klaim (X) naik satu satuan maka nilai variabel kualitas pelayanan klaim ganti pemegang polis (Y) akan mengalami kenaikan 0,530 satuan.

Berdasarkan hasil pengujian hipotesis dapat diketahui terdapat pengaruh yang signifikan antara kinerja karyawan dalam melayani klaim dengan kualitas pelayanan klaim ganti rugi pemegang polis pada PT. Prudential Life Assurance PRU Future Team Syariah kantor Agency Tuanku Tambusai Pekanbaru, hal ini diketahui dari nilai $\mathrm{F}$ hitung $(9,027)$ lebih besar dari $F$ tabel $(4,07)$. Hubungan antara kinerja karyawan dalam melayani klaim dengan kualitas pelayanan klaim ganti rugi pemegang polis pada PT. Prudential Life Assurance PRU Future Team Syariah kantor Agency Tuanku Tambusai Pekanbaru merupakan hubungan cukup kuat. Hal ini diketahui dari nilai koefisien korelasi bernilai positif sebesar 0,421 yang artinya semakin tinggi kinerja karyawan dalam melayani klaim semakin tinggi pula kualitas pelayanan klaim ganti rugi nasabah pemegang polis pada PT. Prudential Life Assurance PRU Future Team Syariah kantor Agency Tuanku Tambusai Pekanbaru. Pengaruh kinerja karyawan dalam melayani klaim terhadap kualitas pelayanan klaim ganti rugi pemegang polis pada PT. Prudential Life Assurance PRU Future Team Syariah kantor Agency Tuanku Tambusai Pekanbaru sebesar $17,70 \%$ sedangkan sisanya sebesar $82,30 \%$ dipengaruhi oleh faktor lain.

Hasil penelitian menunjukkan bahwa terdapat pengaruh yang signifikan antara bukti fisik, kehandalan, ketanggapan, jaminan, dan empati secara bersama-sama terhadap kualitas pelayanan jasa rahn pada Perum Pegadaian Syariah Kantor Cabang Harapan Raya Pekanbaru.

\section{SIMPULAN}

Berdasarkan analisis data yang dilakukan terhadap permasalahan yang telah dirumuskan, maka dapat diperoleh beberapa kesimpulan sebagai berikut: (1) Kinerja karyawan dalam melayani klaim pada PT. Prudential Life Assurance PRU Future Team Syariah kantor Agency Tuanku Tambusai Pekanbaru tergolong "baik" karena skor empiris dibandingkan dengan skor idealnya sebesar 74,28\% termasuk pada kriteria interpretasi skor 61\% - 80\%;. (2) Kulitas pelayanan klaim ganti rugi pemegang polis pada PT. Prudential Life Assurance PRU Future Team Syariah kantor Agency Tuanku Tambusai Pekanbaru tergolong baik karena skor empiris dibandingkan dengan skor idealnya sebesar 78,60\% termasuk pada kriteria interpretasi skor $61 \%$ - 80\%. (3) Berdasarkan hasil pengujian hipotesis dapat diketahui terdapat pengaruh yang signifikan antara kinerja karyawan dalam melayani klaim dengan kualitas pelayanan klaim ganti rugi pemegang polis pada PT. Prudential Life Assurance PRU Future Team Syariah kantor Agency Tuanku Tambusai Pekanbaru, hal ini diketahui dari nilai $\mathrm{F}$ hitung $(9,027)$ lebih besar dari $F$ tabel $(4,07)$. Hubungan antara kinerja karyawan dalam melayani klaim dengan kualitas pelayanan klaim ganti rugi pemegang polis pada PT. Prudential Life Assurance PRU Future Team Syariah kantor Agency Tuanku Tambusai Pekanbaru merupakan hubungan cukup kuat. Hal ini diketahui dari nilai koefisien korelasi bernilai positif sebesar 0,421. Pengaruh kinerja karyawan dalam melayani klaim terhadap kualitas pelayanan klaim ganti rugi pemegang polis pada PT. Prudential Life Assurance 2, Oktober 2016 ISSN 1412-5382 
PRU Future Team Syariah kantor Agency Tuanku Tambusai Pekanbaru sebesar $17,70 \%$ sedangkan sisanya sebesar $82,30 \%$ dipengaruhi oleh faktor lain.

\section{DAFTAR RUJUKAN}

Al-Arif, M. Nur Rianto. 2010. Dasar-Dasar Pemasaran Bank Syariah, Bandung: Alfabeta.

Burhanuddin. 2010. Aspek Hukum Lembaga Keuangan Syariah. Yogyakarta: Graha Ilmu.

Departamen Agama RI. 1998. Al-Qur'an dan Terjemahan. Semarang: Asy Syifa.

Dewi, Khaira. Kinerja Karyawan dalam Melayani Klaim Ganti Rugi Pemegang Polis Pada PT. Prudential Life Assurance PRU Future Team Syariah Kantor Agency Tuanku Tambusai Pekanbaru. Skripsi, Pekanbaru: Program Studi Ekonomi Syariah Fakultas Agama Islam Universitas Islam Riau.DSN MUI. 2003. Himpunan Fatwa Dewan Syariah Nasional, Edisi Kedua. Jakarta: DSN MUI dan Bank Indonesia.

Endah, Septy Puspa. 2011. Analisis Faktor-faktor yang mempengaruhi Kualitas Pelayanan Jasa Rahn pada Perum Pegadaian Syariah Kantor Cabang Harapan Raya Pekanbaru, Skripsi, Jurusan Ekonomi Islam, Fakultas Agama Islam, Universitas Islam Riau, Pekanbaru.

Fahmi, Irham. 2001. Manajemen Kinerja Teori dan Aplikasi, Bandung: Alfabeta.

Idrus, Muhammad. 2009. Metode Penelitian Ilmu Sosial: Pendekatan Kualitatif dan Kuantitatif, Edisi Kedua, Yogyakarta: Erlangga.

Lupiyoadi, Rambat dan Hamdani. 2006. Manajemen Pemasaran Jasa, Jakarta: Salemba Empat.
Muthohari, Nisrina. 2012. Panduan Praktis Membeli dan Menjual Asuransi, Yogyakarta: Buku Pintar.PT. Prudential Life Assurance. 2011. PRU Fast Start, Jakarta: PRU Sales Academy.

Rianto, Elly dan Abror, Ahmad 2005. Lembaga Keuangan. Jakarta: PT. Rineka Cipta.

Riduwan, 2009. Dasar-Dasar Statistika, Cet. 7, Bandung: Alfabeta.

Rivai, Veithzal. 2004. Manajemen Sumber Daya Manusia untuk Perusahaan, Jakarta: Raja Grafindo,

Soemitra, Andi. 2010. Bank dan Lembaga Keuangan Syariah. Jakarta: Kencana.

Sula, Muhammad Syakir. 2004. Asuransi Syariah (Life and General) Konsep dan Sistem Operasional, Jakarta: Gema Insani.

Suliyanto. 2007. Metode Riset Bisnis, Ed. 1, Yogyakarta: AndiOffset.

Sunyoto, Danang. 2011. Metodologi Penelitan untuk Ekonomi, Cet. 1, Jakarta: Caps..

Susanto, Heru. 2010. Cerdik Memilih Asuransi Jiwa, Jakarta: PT. Bhuana Ilmu Populer.

Tika, Moh. Pabandu. 2006. Metodologi Riset Bisnis, Cet. 1, Jakarta: Bumi Aksara.

Wahyuli, Afrida. 2009. Pengaruh Pelatihan terhadap Kinerja Karyawan pada PT. Bank Perkreditan Rakyat Syariah (BPRS) Berkah Dana Fadhillah Airtiris Kabupaten Kampar, Skripsi, Jurusan Ekonomi Islam, Fakultas Agama Islam, Universitas Islam Riau, Pekanbaru.

Wirdyaningsih, et al., 2002. Bank dan Asuransi Islam Indonesia, Jakarta: Universitas Indonesia.

Zulkifli Rusby, Lolyta Permata dan Septy Puspa Endah. 2011. Jurnal Keilmuan Keislaman Al-Hikmah. Vol. 8, No. 2: 132-150. 
Zuriah, Nurul. 2009. Metodelogi

Jakarta: Bumi Aksara.

Penelitian Sosial dan Pendidikan,

Jurnal Al-hikmah Vol. 13, No. 2, Oktober 2016 ISSN 1412-5382 